\title{
Ethical Challenges and Opportunities at the Edge: Incorporating Spirituality and Religion Into Psychotherapy
}

\author{
John C. Gonsiorek \\ Argosy University - Twin Cities Campus \\ P. Scott Richards \\ Brigham Young University - Provo, scott_richards@byu.edu \\ Kenneth I. Pargament \\ Bowling Green State University \\ Mark R. McMinn \\ George Fox University \\ Follow this and additional works at: https://scholarsarchive.byu.edu/facpub \\ Part of the Student Counseling and Personnel Services Commons
}

\section{Original Publication Citation}

Gonsiorek, J. C., Richards, P. S., Pargament, K. I., \& McMinn, M. R. (2009). Ethical challenges and opportunities at the edge: Incorporating spirituality and religion into psychotherapy. Professional Psychology: Research and Practice, 40 (4), 385-395.

\section{BYU ScholarsArchive Citation}

Gonsiorek, John C.; Richards, P. Scott; Pargament, Kenneth I.; and McMinn, Mark R., "Ethical Challenges and Opportunities at the Edge: Incorporating Spirituality and Religion Into Psychotherapy" (2009). Faculty Publications. 3850.

https://scholarsarchive.byu.edu/facpub/3850

This Peer-Reviewed Article is brought to you for free and open access by BYU ScholarsArchive. It has been accepted for inclusion in Faculty Publications by an authorized administrator of BYU ScholarsArchive. For more information, please contact ellen_amatangelo@byu.edu. 


\title{
Ethical Challenges and Opportunities at the Edge: Incorporating Spirituality and Religion Into Psychotherapy
}

\author{
John C. Gonsiorek \\ Argosy University, Twin Cities \\ Kenneth I. Pargament \\ Bowling Green State University
}

\author{
P. Scott Richards \\ Brigham Young University
}

\begin{abstract}
Incorporating spirituality and religion into psychotherapy has been controversial, but recent contributions have argued the importance and provided foundations for doing so. Discussions of ethical challenges in this process are emerging, and this contribution discusses several preliminary issues, relying on the Resolution on Religious, Religion-Based and/or Religion-Derived Prejudice adopted by the American Psychological Association in 2007, as guidance when used with the American Psychological Association's (2002) Ethical Principles of Psychologists and Code of Conduct. Specifically, this discussion of preliminary challenges addresses competence, bias, maintaining traditions and standards of psychology, and integrity in labeling services for reimbursement. Commentators deepen the discussion, addressing what constitutes minimal competence in this area; effective and truly mutual collaboration with clergy; the high level of ethical complexity and "inherent messiness" of this domain of psychological practice; and the particular challenges of demarcating the boundaries of these domains for regulatory and billing purposes. This discussion offers decidedly preliminary ideas on managing the interface of these domains. Further development is needed before this nascent area approximates precise guidelines or standards.
\end{abstract}

Keywords: psychotherapy, religion, spirituality, ethics, competence

\section{Ethical Challenges Incorporating Spirituality and Religion Into Psychotherapy}

\section{By John C. Gonsiorek}

Survey data suggest that spirituality and religion (see Hill \& Pargament, 2003, for a discussion of the differences between these) are important facets in the lives of most Americans (Gallup Foundation, 2007) and may be related to physical health and emotional well-being (Hill \& Pargament, 2003). Incorporating spiritual and religious concepts into psychotherapy has been controversial but is becoming less so (see Plante, 2007, pp. 891-893). Recent work focuses on clinical applications of spiritual and religious perspectives (Aten \& Leach, 2008; Miller, 1999; Plante, 2009; Richards \& Bergin, 1997; Sperry \& Schafranske, 2005), but conceptual frameworks (Hill \& Pargament,
John C. Gonsiorek received his $\mathrm{PhD}$ in clinical psychology from the University of Minnesota. After many years in independent practice of clinical and forensic psychology, he is now Professor in the PsyD Training Program at Argosy University, Twin Cities. His areas of professional interest include human sexuality, forensic psychology, ethical and professional issues, religion and psychology, and public policy implications of behavioral sciences.

P. SCOTT RICHARDS received his PhD in counseling psychology from the University of Minnesota. He is a professor of counseling psychology at Brigham Young University. His areas of scholarly interest include religious and spiritual issues in psychotherapy and the role of spirituality in eating disorder treatment and recovery. Dr. Richards thanks Rev. George F. Handzo and Rev. Martin G. Montonye at the HealthCare Chaplaincy in New York City, Rev. Dr. Leonard M. Hummel at The Lutheran Theological Seminary at Gettysburg, and Rick Gabbitas at Brigham Young University for their helpful suggestions and assistance with this commentary.
The work on this commentary was supported in part by funding from the John Templeton Foundation.

Kenneth I. Pargament received his $\mathrm{PhD}$ in clinical psychology from the University of Maryland. He is professor in the Clinical Psychology $\mathrm{PhD}$ Program at Bowling Green State University. His areas of research and practice focus on the psychology of religion and spirituality; the interface between religion, spirituality, trauma, coping, and health; and the development and evaluation of spiritually integrated approaches to treatment.

MARK R. McMinn received a PhD in clinical psychology from Vanderbilt University. He is currently a professor of psychology at George Fox University, Newberg, Oregon. His primary research interests pertain to spiritual and religious issues in psychotherapy.

CORRESPONDENCE CONCERNING THIS ARTICLE should be addressed to John C. Gonsiorek, 3514 Lilac Lane, Minnetonka, MN 55345. E-mail: john_gonsiorek@yahoo.com 
2003), research applications (Miller \& Thoresen, 2003), and ethical analyses are also emerging (Plante, 2007, 2009, chap. 6).

A massive $(N=35,556)$ survey on religion in the United States by the Pew Forum on Religion and Public Life (2008a) further illustrates the importance of this issue. While $56 \%$ of their total sample reported that religion is "very important" in their lives, $44 \%$ also reported that they have switched religious affiliation, moved from religious nonaffiliation to specific affiliation, or moved from specific affiliation to nonaffiliation. The overall picture of religious life in U.S. adults emerging from this study is one of "constant movement" as characteristic of a fractionated yet vibrant "American religious marketplace." It is reasonable to conclude that religion is very important both to those who retain affiliation with their initial faith traditions but to those whose religious affiliations change over time. It is inevitable, therefore, that such deeply held aspects of the human experience will regularly express themselves in clients' presentations for psychological services.

This contribution discusses some of the ethical challenges associated with incorporating spiritual and religious concepts in psychotherapy. It is not intended as comprehensive, instead targeting some preliminary issues, the resolution of which can assist psychologists in ethically and effectively incorporating this important component of client diversity in psychotherapy services. The American Psychological Association's (APA; 2008) recently adopted Resolution on Religious, Religion-Based and/or ReligionDerived Prejudice (hereinafter referred to as Resolution) is highlighted as providing guidance beyond requirements of the American Psychological Association's (APA; 2002) Ethical Principles of Psychologists and Code of Conduct (hereinafter referred to as Ethics Code).

\section{Competence}

On what basis do psychologists conclude that they possess adequate competence with spiritual and religious issues? Competence in the services provided is a fundamental ethical requirement (APA, 2002). The assumption that personal religious faith (or equally held agnosticism or atheism) is adequate is an error. Analogy illustrates the weakness of this assumption. Asserting that one's personal ethnicity, gender, health or ability status, or sexual orientation automatically creates professional competence with these issues is erroneous. For example, psychologists competent as neuropsychologists, who know little of the psychological aspects of their own background status beyond survey courses and personal experience, are competent as neuropsychologists but are not competent in issues of their background status.

This erroneous assumption also trivializes religious and spiritual concerns as an area of true expertise: Are these issues so insubstantial that mere personal experience and reflection suffice as expertise? A solution is that sufficient competence in spiritual and religious issues in psychology should resemble competence in other areas of expertise: a sufficiently broad and detailed combination of course work, supervised experience, continuing education, professional reading, consultation, and other standard training vehicles that together are satisfactory to licensing boards and ethics committees.

Psychologists additionally trained as clergy or theologians might appear to satisfy competence needs. This is not so. Such training provides depth, but rarely breadth; individuals are typically trained only in particular faith traditions. Unless the competence is limited to that particular tradition, they will have the same challenges as do other psychologists in developing general competence in spiritual and religious issues. Such dually trained psychologists also face unique challenges. The intellectual and philosophical bases of religious training fit imprecisely, perhaps poorly, with scientific traditions of psychology, requiring extra care in translation, as is addressed below. Additionally, most who opt for religious training are understandably partisan about their faith and may have to work harder to be receptive to clients from other traditions.

Personal faith and spirituality can certainly serve as important components in expertise. Psychologists who establish competence in areas related to features of their own status are likely to be personally animated and genuinely informed by personal experiences. Such experiences, however, are not sufficient for competence; standard training mechanisms remain central. They are not even necessary conditions: As behavioral scientists, our expertise must be learnable by those who do not have personal experience. Expertise in spiritual and religious issues must also be learnable regardless of personal faith. Otherwise, such expertise is removed from the realm of psychological services and recast as ministerial.

This focus on acquired skill instead of personal experience in defining competence helps minimize "balkanization": the assumption that clients are best treated by psychotherapists who are like them. This position ultimately means that many clients will be without services, because matching is impractical. Some clients express strong preferences for working with psychotherapists who share a particular status. Their reasons may be sound (i.e., a history of discrimination such that trusting an outsider is too difficult to allow a therapeutic process) or not (unreflective assumption that they can be helped only by someone just like them). The profession, however, should promote a competency-based, not affiliation-based, norm for client-psychotherapist matching. Balkanization undermines the tradition of psychology as a behavioral science consisting of learnable skills. It erodes basic expectations that all psychologists acquire competencies in demonstrable and orderly ways if they claim them and strive to sensitively and effectively serve a diversity of clients.

\section{Bias}

Negative biases toward spirituality and religion are serious but often apparent. They include a broad range from the following: nonreligious psychologists who perceive client faith as indicative of rigidity, low intelligence, or poor coping; nonreligious psychologists who perceive spiritual and religious concerns as of little consequence, thereby disparaging an important aspect of clients' worldview; religious psychologists who view nonreligious clients as immoral, defective, or untrustworthy; religious psychologists who view clients from a tradition other than their own as misguided; and other variations. What these share is that psychotherapists' personal views on spirituality and religion serve as a basis for negative evaluation of clients' views on spirituality and religion. As the Resolution (APA, 2008) stated: "Indeed, it is a paradoxical feature of these kinds of prejudices that religion can be both target and victim of prejudice, as well as construed as justification and imperative for prejudice" (p. 431). 
An often-overlooked negative bias variation involves ignoring or disparaging diversity within a faith tradition. For example, consider what it means to be "Catholic." To the Vatican, this concept is clear, consisting of adherence to particular belief and practice. Few, however, define their faith as the institutional hierarchy does; the lived reality of religious faith bears only approximate resemblance to textbook theology. Those identifying as Catholic may give variable saliency to orthodox theological understandings of faith, liturgy, beliefs about social justice, beliefs about abortion, inclusion in social networks, and others. Individuals might emphasize some components over others, behaviorally ignore while verbally maintain nondisagreement with others, actively reject some, and so on. Identified Catholics are in fact diverse, with only a subset accurately defined by orthodox theology.

Data from a subsection of the Pew Forum on Religion and Public Life (2008b) illustrate this intragroup diversity. Examining their Catholic sample $(n=8,054), 18 \%$ believed that abortion should be illegal in all cases; $16 \%$ believed it should be legal in all cases; and the rest fell on a continuum in between, with $48 \%$ believing it should be more legal than not. Fifty-eight percent believed that homosexuality should be acceptable, and $30 \%$ believed that it should be discouraged. Data from other denominations document similar inconsistency between official institutional positions and their membership.

Predicting attitudes, beliefs, and behavior from denominational affiliation is imprecise, given such heterogeneity, and impossible in individual cases. Psychologists risk stereotyping religious clients by assuming that what faith means to them is as it is defined by the faith institution. Such psychologists, in effect, subtly enforce religious orthodoxy. The client is the client; the religious institution is not. Egregious variations of this can occur when religious psychologists aligned with faith institutions use psychological services to enforce orthodoxy. The Resolution (APA, 2008) addresses this issue: "psychologists are encouraged to recognize that it is outside the role and expertise of psychologists as psychologists to adjudicate religious or spiritual tenets ..." (p. 433), and also "... the American Psychological Association views no religious, faith, or spiritual tradition, or lack of tradition, as more deserving of protection than another..." (p. 432). In other words, psychology has no legitimate function advocating for religious orthodoxy or dissent.

Positive biases can be as destructive as negative. With religious clients, this can take the form of seeing such clients in a morally idealized manner, being "better." Positive biases can result in serious problems being misconstrued as diversity and in behaviors with significant mental health implications being ignored. With religious clients, examples include seeing selfdestructive moral scrupulosity as religious devotion; accepting abuse of children, women, sexual minorities, and nonbelievers as justifiable; taking assertions of faith-based transformation as evidence of behavioral change when it is implausible; and similar pitfalls. As the Resolution (APA, 2008) noted: "The right of persons to practice their religion or faith does not and cannot entail a right to harm others or to undermine the public good" (pp. 431-432).

With negative biases, clients are treated as second class by a manifest process of disparagement. With positive biases, clients are treated as second class by a more latent process of not being seen as they actually are or by not receiving psychologists' expertise and concern when genuine problems are misconstrued. Biases of any variety diminish psychological services being provided and so require psychologists to manage them. Management starts with the routine competency building activities described above, but self-examination and consultation are recommended to screen for biases that derive from deeper sources than do knowledge insufficiency.

\section{Maintaining Traditions and Standards of Psychology}

Incorporating spiritual and religious issues into psychotherapy will likely become ethically risky when this interface is viewed as sufficiently special such that deviations from psychological traditions and standards are warranted. The opposite argument is instead more sensible: in a challenging nascent area, holding standards closer is well advised. Maintaining psychology's standards and traditions is a complex undertaking, however, because it involves both specific practice challenges and consistency with broader scientific epistemology and methodology.

Multiple relationships are an example of a specific practice challenge, because expected boundaries can operate differently in religious traditions. A psychotherapist sensitive to religious concerns of a client who feels misunderstood about them may inadvertently acquire client expectations about boundaries normative within the religious cohort. These may not match professional standards, creating opportunities for misunderstanding and disappointment. A risk-management approach that effectively uses initial informed consent can remedy problems with erroneous expectations. This area can be especially risky for dually trained clergy/ psychologists, because appropriate and expected boundaries differ between these roles. For example, it is normative for clergy to engage in fundraising with those whom they serve, but psychologists cannot do so with their clients.

A basic boundary concern entails whose religious diversity matters in psychological services. The answer can only be the client's. Psychologists who maintain that they are diminished by working with clients whose beliefs or behavior impinge upon the psychologists' beliefs have a peculiarly self-absorbed conceptualization of diversity and forget the core rationale for psychological services: serving clients.

The larger issue of consistency with broader scientific epistemology and methodology can be more elusive. The Resolution can offer guidance here, because it devotes considerable effort to differentiating psychology and religion:

It is important for psychology as a behavioral science, and various faith traditions as theological systems, to acknowledge and respect their profoundly different methodological, epistemological, historical, theoretical, and philosophical bases.... While both traditions may arrive at public policy perspectives operating out of their own traditions, the bases for these perspectives are substantially different. (APA, 2008, p. 432)

Furthermore, [w] hereas contemporary psychology as well as religious and spiritual traditions all address the human condition, they often do so from distinct presuppositions, approaches to knowledge, and social roles and contexts, and while these differences can be enriching and may stimulate fruitful interaction between these domains, they also can present opportunities for misunderstanding and tension around areas of shared concern. (APA, 2008, p. 432) 
Recent years have seen regular conflicts within psychology deriving from these broader differences. The American Psychological Association has experienced a number of painful internal debates of the form in which reasoned conclusions derived from the behavioral sciences literature, and especially their public policy implications, are at odds with the religious perspectives of some members of APA and the public. The desired professional response to these challenges is to engage in dialogue and research further. Confusing or actively obfuscating what is psychologically sound to make it compatible with particular religious perspectives is poor psychology and worse theology. Focal points of conflict typically involve sexuality and gender roles but can occur wherever psychology and a religious perspective disagree. This conflict is inevitable to some degree because scientific reasoning - with its skepticism, need for evidence, lack of ultimate certainty or truth, theory evolving in response to data, ambiguity, and insistence on appropriate methodologies - is a weak fit with theological systems of thought characterized by central truths, revealed knowledge, more static constructs, and unverifiability (see Gonsiorek, 2004, pp. 756-758, for a further discussion).

Religion and spirituality are important aspects of human diversity; these concerns are important to our clients; and these concerns are interesting, important, and legitimate subjects of psychological research. These features require that psychology not flinch from exploring this integration. But the profound differences between psychology and religion also require that we do so cautiously, with frank acknowledgment of the challenges.

\section{What To Name It and Whether To Bill}

An infrequently discussed concern is how psychologists label spiritually and religiously oriented psychotherapy and bill for it. This issue ranges from nonproblematic to frankly fraudulent. Nonproblematic variations include helping religiously oriented clients understand mental health problems from a religious vantage. For example, Haughn (2007) used the Book of Job to help understand one's trauma symptoms and recovery, and Johnson (2006) detailed how rational emotive behavior therapy is congruent and useful for some Christian counseling perspectives.

At the problematic end, examples include providing religious instruction and billing it as psychotherapy, creating false diagnoses and treatment plans to cover the actual activities; or labeling theological difference and noncompliance or spiritual dilemmas as mental health symptoms. Such cases involve misrepresentation, and when submitted for insurance reimbursement, sometimes criminal fraud. The differentiations here involve an honest appraisal of whether the services are focused on mental health or religious and spiritual goals and whether adaptations of psychological techniques to render them acceptable to particular religious clients fall within a reasonable standard of care and are consistent with the techniques' requirements and limitations.

Risks to ethical practice often involve a careless slide from religiously sensitive psychological services to primarily religious services. For example, treatment of a mood problem with a religious client can benefit from framing the experience through the client's spiritual framework. Should the client request to primarily spend the sessions in joint prayer, however, ethical concerns emerge: Is the service psychological or religious? Is this an unpredictable multiple relationship? Should it be billed? The psy- chologist who then enforces appropriate limits faces risks: Will the client see limit setting as a betrayal by a psychotherapist who has so far been religiously sensitive? Preventive risk management, especially via informed consent, is a key strategy. It may be wise for any psychotherapy using religious and spiritual concepts to include in initial informed consent a detailed discussion of differences between psychology and religion, limits of the psychologists' activities, multiple relationships, and what can be legitimately billed. Obtaining regular objective consultation near grey areas is recommended. Red flags include psychotherapist reluctance to discuss the situation with a colleague operating outside the religious framework or with the insurer regarding billing.

This brief discussion of preliminary ethical challenges incorporating spiritual and religious concepts in psychotherapy highlights a few concerns currently warranting attention; others will likely emerge as this interface deepens. The need for psychology to include the spiritual and religious diversity so important to many clients and to a full understanding of humanness is apparent. Equally important is the need for psychology to maintain its own identity, traditions, standards, and values as a behavioral science. While it remains to be seen if and how well the dilemmas are resolved, neither giddy embrace nor cold disdain is an appropriate or effective resolution to the interface challenges of these two different disciplines and ways of knowing the human condition. Acknowledgment and respect for difference while seeking areas of common ground have a higher probability of success. The APA Ethics Code as bedrock, joined with the Resolution as guidance and amplification, offers a promising approach.

The invited commentaries to follow address these and other relevant areas of concern for practicing psychologists. Practical recommendations are provided for effectively and sensitively addressing clients' beliefs and concerns relevant to religious and spiritual issues.

\section{References}

American Psychological Association. (2002). Ethical principles of psychologists and code of conduct. American Psychologist, 57, 1060-1073.

American Psychological Association. (2008). Resolution on religious, religion-based and/or religion-derived prejudice. American Psychologist, 63, 431-434.

Aten, J. D., \& Leach, M. M. (Eds.). (2008). Spirituality and the therapeutic process: A comprehensive resource from intake to termination. Washington, DC: American Psychological Association.

Gallup Foundation. (2007). Religion. Retrieved August 30, 2008, from http://www.gallup.com/poll/1690/Religion.aspx

Gonsiorek, J. C. (2004). Reflections from the conversion therapy battlefield. Counseling Psychologist, 32, 750-759.

Haughn, W. C. (2007, June). Psychotherapists' views of a book of job model for understanding and treating traumatic stress. Dissertation $A b-$ stracts International, 67(12), Section B, p. 7375. (UMI No. 1240709211)

Hill, P., \& Pargament, K. I. (2003). Advances in the conceptualization and measurement of religion and spirituality: Implications for physical and mental health research. American Psychologist, 58, 64-74.

Johnson, S. (2006). The congruence of the philosophy of rational emotive behavior therapy within the philosophy of mainstream Christianity. Journal of Cognitive and Behavioral Psychotherapies, 6, 45-55.

Miller, W. R. (Ed.). (1999). Integrating spirituality into treatment. Washington, DC: American Psychological Association.

Miller, W. R., \& Thoresen, C. E. (2003). Spirituality, religion, and health: An emerging research field. American Psychologist, 58, 24-35. 
Pargament, K. I. (1997). The psychology of religious coping: Theory, research, practice. New York: Guilford Press.

Pew Forum on Religion and Public Life. (2008a). U.S. religious landscape survey: Final reports. Retrieved August 30, 2008, from http:// religions.pewforum.org/reports

Pew Forum on Religion and Public Life. (2008b). U.S. religious landscape survey: Comparisons. Retrieved August 30, 2008, from http:// religions.pewforum.org/comparisons

Plante, T. G. (2007). Integrating spirituality and psychotherapy: Ethical issues and principles to consider. Journal of Clinical Psychology, 63, 891-902.

Plante, T. G. (2009). Spiritual practices in psychotherapy: Thirteen tools for enhancing psychological health. Washington, DC: American Psychological Association.

Richards, P. S., \& Bergin, A. E. (1997). A spiritual strategy for counseling and psychotherapy. Washington, DC: American Psychological Association.

Sperry, L., \& Shafranske, E. P. (Eds.). (2005). Spiritually oriented psychotherapy. Washington, DC: American Psychological Association.

\section{Toward Religious and Spiritual Competence for Psychologists: Some Reflections and Recommendations}

By P. Scott Richards

Dr. Gonsiorek (Gonsiorek, Richards, Pargament, \& McMinn, 2009) has raised important questions and provided valuable perspectives concerning some ethical challenges associated with incorporating spirituality and religion into psychotherapy. He pointed out that competence in the services that psychologists provide "is a fundamental ethical requirement" (Gonsiorek et al., 2009, p. 386). In other words, if psychologists wish to incorporate religion and spirituality into their practices, they need to make sure that they are competent to do so. I would add that in my view, all psychologists are ethically obligated to incorporate religion and spirituality into their practices, at least to the extent that they can "ensure the competence of their services" with religious and spiritual clients (American Psychological Association, 2002, p. 1064).

One thought-provoking and important question posed by Gonsiorek was, "On what basis do psychologists conclude that they possess adequate competence with spiritual and religious issues?" This question stimulated me to reflect on what I regard as minimal areas of religious and spiritual competence for psychologists.

\section{Religious-Spiritual Competency Questions}

I constructed a brief list of religious-spiritual self-evaluation "minimal competency" questions. My list is not empirically derived, nor do I claim that it is comprehensive. But I personally think it would be ideal if all psychotherapists could respond affirmatively to these questions.

1. Do I have the ability to create a spiritually safe and affirming therapeutic environment for my clients?

2. Do I have the ability to conduct an effective religious and spiritual assessment of my clients?
3. Do I have the ability to use or encourage religious and spiritual interventions, if indicated, in order to help clients access the resources of their faith and spirituality during treatment and recovery?

4. Do I have the ability to effectively consult and collaborate with, and when needed, refer to clergy and other pastoral professionals?

I do not have space to write more about each of these four competency questions in this brief commentary, but much has been written about each of them in other sources (e.g., Aten \& Leach, 2008; Plante, 2009; Richards \& Bergin, 2000, 2005; Sperry \& Shafranske, 2005). Gonsiorek raised several questions regarding competency issues and role boundaries pertaining to psychologists and clergy, and so I wish to focus the remainder of my commentary on my fourth competency question. On the basis of several recent studies and articles, I believe that many psychologists would benefit from additional information and encouragement about how to work effectively with clergy and other pastoral professionals.

\section{Suggestions for Collaboration Between Psychologists and Pastoral Professionals}

During the past couple of decades the professional literature on psychologist-clergy collaboration has grown (e.g., McMinn, Aikins, \& Lish, 2003; Milstein, Manierre, Susman, \& Bruce, 2008; Weaver, Samford, Kline, Lucas, Larson, \& Koenig, 1997). Research to date indicates that psychologist-clergy collaboration occurs relatively infrequently and that referral patterns tend to be unidirectional, with clergy doing most of the referring to psychologists (McMinn, Chaddock, Edwards, Lim, \& Campbell, 1998). A number of barriers to more effective collaboration have been identified, including psychologists' lack of education and training about (a) religion and spirituality, (b) the roles of clergy and pastoral professionals, and (c) when and how to appropriately consult, refer, and collaborate with religious professionals (McMinn et al., 1998; Oppenheimer, Flannelly, \& Weaver, 2004). Lack of trust and disparate values have also been identified as barriers to collaboration (McMinn et al., 1998).

Fortunately, many helpful suggestions have been offered in recent publications to assist psychologists in working more effectively with clergy and pastoral professionals. Here, I offer a few suggestions for psychologists on the basis of this literature as well as on my own recent experiences in collaborating with clergy and other pastoral professionals at the HealthCare Chaplaincy in New York City.

1. Seek more education and understanding about religious and spiritual aspects of diversity. Take courses, read books and articles, and watch videos about the world religions, psychology of religion, and spiritual approaches for counseling and psychotherapy. This understanding will provide a conceptual foundation for respectful and collaborative relationships with clergy and other pastoral professionals.

2. Seek more education and understanding about the roles and professions of clergy, chaplains, and pastoral counselors. Table 1 presents a brief summary of roles, training, and professional organizations of pastoral professionals who engage in direct service to clients in religious, health care, military, and many other set- 
Table 1

Roles, Training, and Professional Organizations of Direct Service Provider Pastoral Professionals

\begin{tabular}{|c|c|c|c|}
\hline Profession & Definition and role & Required education and certification & $\begin{array}{c}\text { Professional organizations and contact } \\
\text { information }\end{array}$ \\
\hline Pastoral counselors & $\begin{array}{l}\text { Certified mental health professionals who } \\
\text { have in-depth religious or theological } \\
\text { training. Provide spiritual and } \\
\text { emotional counseling and } \\
\text { psychotherapy within a church, parish, } \\
\text { or synagogue or in other settings such } \\
\text { as hospitals, homeless shelters, prison, } \\
\text { military base, college campus, or } \\
\text { independent counseling center. }\end{array}$ & $\begin{array}{l}\text { 1. Three-year professional degree from } \\
\text { a seminary (postbaccalaureate) } \\
\text { 2. Masters or doctoral degree in the } \\
\text { mental health field } \\
\text { 3. Many pastoral counselors receive } \\
\text { training and experience with grief } \\
\text { and bereavement; critical incident } \\
\text { stress management; and } \\
\text { multicultural diversity }\end{array}$ & $\begin{array}{l}\text { American Association of Pastoral } \\
\text { Counselors (www.aapc.org) } \\
\text { The College of Pastoral Supervision and } \\
\text { Psychotherapy (www.pastoralreport.com/ } \\
\text { about.html) }\end{array}$ \\
\hline Clinical chaplains & $\begin{array}{l}\text { Chaplains are credentialed clergy or } \\
\text { pastoral professionals who serve in a } \\
\text { variety of institutions, including the } \\
\text { military, hospitals, prisons, } \\
\text { corporations, and universities. } \\
\text { Chaplains are authorized to perform } \\
\text { religious services and practices on } \\
\text { behalf of their clients. They also } \\
\text { provide spiritual and emotional support } \\
\text { and counsel. }\end{array}$ & $\begin{array}{l}\text { 1. } 72 \text { semester hr graduate theological } \\
\text { degree (postbaccalaureate) } \\
\text { 2. One to four units of clinical pastoral } \\
\text { education } \\
\text { 3. Ordination or commissioning to } \\
\text { function in a ministry of pastoral } \\
\text { care } \\
\text { 4. Ecclesiastical endorsement by a } \\
\text { faith group } \\
\text { 5. Many chaplains receive training and } \\
\text { experience with grief and } \\
\text { bereavement; critical incident stress } \\
\text { management; and multicultural } \\
\text { diversity }\end{array}$ & $\begin{array}{l}\text { Association of Professional Chaplains } \\
\text { (www.professionalchaplains.org) } \\
\text { National Association of Catholic } \\
\text { Chaplains (www.nacc.org) } \\
\text { National Association of Jewish } \\
\text { Chaplains (www.najc.org) } \\
\text { College of Pastoral Supervision and } \\
\text { Psychotherapy (www.pastoralreport.com/ } \\
\text { about.html) }\end{array}$ \\
\hline Clergy & $\begin{array}{l}\text { Clergy are ordained or set apart by their } \\
\text { faith group as a religious leader (e.g., } \\
\text { minister, priest, pastor, rabbi, bishop). } \\
\text { Clergy minister to the religious, } \\
\text { spiritual, and emotional needs of } \\
\text { members of their faith group through } \\
\text { preaching, teaching, and counseling. }\end{array}$ & $\begin{array}{l}\text { Great variability in education } \\
\text { requirements, ranging from no } \\
\text { formal theological training to } \\
\text { formalized theological training that } \\
\text { ranges in length from } 3 \text { to } 6 \text { years } \\
\text { and leads to graduate degree (e.g., } \\
\text { Master of Divinity, Doctorate of } \\
\text { Ministry) }\end{array}$ & $\begin{array}{l}\text { To list all of the many professional } \\
\text { organizations for clergy is not } \\
\text { possible in this table. The Council on } \\
\text { Higher Education Accreditation } \\
\text { (www.chea.org) is an accreditor of } \\
\text { accreditors for seminary training } \\
\text { programs }\end{array}$ \\
\hline
\end{tabular}

tings. Clergy, chaplains, and pastoral counselors are front-line mental health workers in the sense that many people struggling with psychological and relationship problems go to them first for help (McMinn et al., 1998; Oppenheimer et al., 2004). Although Gonsiorek (Gonsiorek et al., 2009, p. 386) may be correct when he writes that clergy "are typically trained only in particular faith traditions," this is usually not the case for chaplains and pastoral counselors. Chaplains and pastoral counselors receive a breadth of training and supervision in theology and religion that prepares them to work in spiritually sensitive and respectful ways with people from a diversity of religious-spiritual traditions (Clinebell, 1984; Paget \& McCormack, 2006).

3. Seek to establish respectful collaborative relationships with clergy, chaplains, and pastoral counselors in the community. McMinn and his colleagues have written about respect and communication as two basic competencies for working collaboratively with clergy (McMinn et al., 2003). Taking the time to make contact and communicate respectfully with pastoral professionals will help lay the foundation for effective collaboration and referral practices between psychologists and clergy, chaplains, and pastoral counselors. Contact information for pastoral professionals can be obtained through phone books, Web sites, religious organizations, and professional organizations. Clients can be asked if they would like to sign a release and provide contact information for their clergy persons so that their psychologists can consult or refer if indicated (McMinn et al., 2003; Richards \& Bergin, 2005).
There are numerous potential benefits to effective psychologistpastoral professional collaboration. For example, clergy and other pastoral professionals can often be of great assistance in helping clients more fully access the social and spiritual resources of their religious beliefs and community during treatment. Gonsiorek (Gonsiorek, et al., 2009) raised concerns about psychologists violating professional role boundaries by carelessly sliding "from religiously sensitive psychological services to primarily religious services" (p. 388). Collaborative relationships with pastoral professionals can help psychologists keep their role boundaries clear so that they do not engage in ecclesiastical functions that are more appropriately performed by clergy or other pastoral professionals (Richards \& Bergin, 2005).

4. Seek to gain more understanding about client issues and contexts when referral or consultation with pastoral professionals may be indicated. When I asked several pastoral professionals when they would like a psychologist to consult with them or refer, they suggested a number of issues and contexts in which they would appreciate it:

(a) You are struggling to understand or feel confused by the religious beliefs or thought world of a religious client.

(b) You are wondering whether a religious client's religious beliefs are healthy and normative or unhealthy and idiosyncratic. 
(c) You believe a client's religious beliefs may be keeping him or her emotionally stuck.

(d) A client expresses feelings of guilt that seem to originate in violations of his or her religious beliefs and values.

(e) A client expresses a desire to reconnect with previously held religious beliefs and community.

(f) A client raises questions about God, or a higher power, or other sources of hope.

(g) A client expresses a desire to participate in or experience a religious ritual, or inquires about spiritualreligious resources.

(h) A religious client is severely depressed and socially isolated.

(i) A religious client is suffering from serious illness, loss, or grief.

There are many other potential issues and contexts in which consultation with or referral to a pastoral professional may be indicated. As psychologists gain more understanding about religious and spiritual aspects of diversity, and as they grow in expertise in incorporating spirituality into treatment, they will find it easier to recognize when consultation, collaboration, or referral to pastoral professionals is indicated.

In conclusion, I thank Dr. Gonsiorek for his thought-provoking article about the ethics of incorporating spirituality and religion into psychotherapy. Reflection and dialogue about the issues he raised, and additional issues, are needed so that our ability to provide effective and ethical spiritually oriented treatment options for clients continues to grow.

\section{References}

American Psychological Association. (2002). Ethical principles of psychologists and code of conduct. American Psychologist, 57, 1060-1073.

Aten, J. D., \& Leach, M. M. (2008). Spirituality and the therapeutic process: A comprehensive resource from intake to termination. Washington, DC: American Psychological Association.

Clinebell, H. (1984). Basic types of pastoral care and counseling: Resources for the ministry of healing and growth. Nashville, TN: Abingdon Press.

Gonsiorek, J. C., Richards, P. S., Pargament, K. I., \& McMinn, M. R. (2009). Ethical challenges and opportunities at the edge: Incorporating spirituality and religion into psychotherapy. Professional Psychology: Research and Practice, 40, 385-395.

McMinn, M. R., Aikins, D. C., \& Lish, R. A. (2003). Basic and advanced competence in collaborating with clergy. Professional Psychology: Research and Practice, 34, 197-202.

McMinn, M. R. (2006). Christian counseling [DVD in APA Psychotherapy Video Series]. Washington, DC: American Psychological Association.

McMinn, M. R., Chaddock, T. P., Edwards, L. C., Lim, B. R. K. B., \& Campbell, C. D. (1998). Psychologists collaborating with clergy. Professional Psychology: Research and Practice, 29, 564-570.

Milstein, G., Manierre, A., Susman, V. L., \& Bruce, M. L. (2008). Implementation of a program to improve the continuity of mental health care through clergy outreach and professional engagement (C. O. P. E.). Professional Psychology: Research and Practice, 39, 218-228.
Oppenheimer, J. E., Flannelly, K. J., \& Weaver, A. J. (2004). A comparative analysis of the psychological literature on collaboration between clergy and mental-health professionals-Perspectives from secular and religious journals: 1970-1999. Pastoral Psychology, 53, 153-162.

Paget, N. K., \& McCormack, J. R. (2006). The work of the chaplain. Valley Forge, PA: Judson Press.

Plante, T. G. (2009). Spiritual practices in psychotherapy: Thirteen tools for enhancing psychological health. Washington, DC: American Psychological Association.

Richards, P. S., \& Bergin, A. E. (Eds.). (2000). Handbook of psychotherapy and religious diversity. Washington, DC: American Psychological Association.

Richards, P. S., \& Bergin, A. E. (2005). A spiritual strategy for counseling and psychotherapy (2nd ed.). Washington, DC: American Psychological Association.

Sperry, L., \& Shafranske, E. P. (Eds.). (2005). Spiritually oriented psychotherapy. Washington, DC: American Psychological Association.

Weaver, A. J., Samford, J. A., Kline, A. E., Lucas, L. A., Larson, D. B., \& Koenig, H. G. (1997). What do psychologists know about working with the clergy? An analysis of eight APA journals: 1991-1994. Professional Psychology: Research and Practice, 28, 471-474.

\section{The Psychospiritual Character of Psychotherapy} and the Ethical Complexities That Follow

\section{By Kenneth I. Pargament}

One of the most important functions of ethical standards and discussions is to demarcate clear boundaries between the acceptable and the unacceptable. Boundaries are especially needed when psychologists face the thorny religious and spiritual issues that can arise in psychotherapy. John Gonsiorek addressed this need earlier in this article. Highlighting the fundamental theoretical and methodological differences between psychology and religion as disciplines, Gonsiorek underscored the importance of working within one's own professional areas of competence. He then provided several important and clear-cut ethical recommendations. For example, he maintained that religious and spiritual experience, reflection, devotion, or formal training do not establish competence in the area of spiritually integrated psychotherapy. Conversely, a lack of personal spirituality or religiousness does not disqualify a practitioner from the development of skills in spiritually integrated psychotherapy. And he insisted that practitioners be alert to their own positive as well as negative religious and spiritual biases and stereotypes. Valuable as they are, these recommendations are only a start, as Gonsiorek himself acknowledged. Further advances in this area, I believe, will rest on the recognition that ethical complexities are part and parcel of a spiritually sensitive psychotherapy.

Dealing with religious and spiritual issues in psychotherapy is inherently messy. Why? In part, because religion and science are not totally separable. Although we can draw contrasts between contemporary psychology and religious traditions, these contrasts can be overdone (see Barbour, 1974). Values, subjectivity, and judgment are an intrinsic part of science, from the choice of subject matter and criterion for statistical significance to the ways data are interpreted and theories revised. On the other hand, religion does not reject critical reflection or evaluation of the external world; it too is vitally concerned about the relationship between metaphysical matters and day-to-day life. 
Working with religious and spiritual issues in psychotherapy is also messy because the spiritual dimension is inextricably interwoven into the character of psychotherapy - in clients, in psychotherapists, and in the process of psychotherapy itself (see Pargament, 2007). With respect to clients, there is a considerable empirical literature now that demonstrates significant relationships between indicators of religiousness and spirituality and indicators of psychological, social, and physical health and well-being (see Koenig, McCullough, \& Larson, 2001). Because these dimensions of life are so interconnected, attempts to create change in one dimension are likely to impact another. For instance, Tisdale et al. (1997) evaluated the effect of a psychiatric inpatient treatment program that was secular in nature, offering patients individual, group, milieu, and psychotropic interventions. As was expected, the patients made significant improvements in their personal adjustment. However, patients also showed unexpected shifts toward more positive images of God. This kind of finding calls into question the assumption that psychotherapy, even in secular forms, can be fully disconnected from the religious and spiritual lives of clients. Rather than establish ethical standards that place religious and spiritual dialogue outside the purview of psychotherapy, guidance is needed to help practitioners engage in religious and spiritual conversation openly and respectfully.

With respect to psychotherapists, practitioners cannot divorce evaluations of a client's religiousity and spirituality from the assessment process in psychotherapy. Empirical studies indicate that religion and spirituality can be therapeutic resources that facilitate a client's health and well-being. In other instances, religion and spirituality can be part of the problem, essentially making bad matters worse. Whether religion and spirituality are part of the solution or part of the problem is an important and legitimate assessment question for psychotherapists. Certainly, these assessments must be made with due attention to personal biases and sensitivity to the legitimacy of diverse religious and spiritual world views and traditions. However, there is some evidence to suggest that psychotherapists as a whole are able to form these kinds of spiritually sensitive judgments.

Butter and Pargament (2003) asked 83 mental health professionals and 83 clergy to assess the level of adjustment of people depicted in vignettes. The characters in the vignettes varied in the degree to which they displayed a well-integrated spirituality. For instance, in one example of higher spiritual integration, the character surrendered the control in his life to God after doing everything he could do to find a cure for an invasive form of cancer. In a vignette illustrating poorer spiritual integration, the character surrendered control in his life to God as a way of coping with a treatable medical illness. Mental health professionals uniformly judged the characters in the well-integrated spiritual vignettes as better adjusted than those in the poorly integrated spiritual vignettes. Moreover, mental health professionals did not differ from clergy in their assessments. These findings suggest that practitioners do, in fact, attend to the religious and spiritual dimension in their evaluations of a client's adjustment and can do so in ways that are reliable and congruent with a larger religious world view. This should come as no great surprise. After all, psychotherapists also consider a client's social and physical functioning in the assessment process. Why should religion and spirituality be any different? We cannot and should not disconnect religion and spirituality from the evaluative process in psychother- apy. The challenge for practitioners is how to evaluate the place of religion and spirituality in the life of the client in sensitive and respectful ways.

Finally, religious and spiritual issues cannot be fully removed from the process of psychotherapy itself. As a case in point, Rye et al. (2005) compared the effectiveness of secular and religiously based forgiveness programs for former spouses. Although the two programs proved to be equally effective in facilitating forgiveness, the follow-up interviews revealed a surprising finding. Asked to note the resources that were most helpful to them in the forgiveness process, participants responded with "turning to God for help" and "praying for the person who wronged them." And these were participants in the secular forgiveness therapy group! Clearly, religion and spirituality were being interwoven into the psychotherapy process, albeit in ways unknown to the psychotherapists. Rather than attempt to separate religion and spirituality from psychotherapy, practitioners should become more aware of the ways religion and spirituality express themselves in the therapeutic process.

Ethical complexity is to be expected when working in this area because people are by nature complex, multidimensional, biopsycho-socio-spiritual beings. Practitioners will encounter clients who engage in problematic practices that are supported by a religious tradition, such as the shunning of others who violate church precepts. Psychotherapists will face clients who express sentiments that are deeply personally offensive, such as the Muslim psychotherapist whose client makes anti-Islamic slurs. Practitioners will struggle with the issues that arise when clients' spiritual goals and values collide with their other strivings, such as the devout wife whose husband tells her he is gay but wants to remain in the marriage. Cases of these kinds defy easy solutions based on black-and-white rules. Because there is a basic psychospiritual character to psychotherapy, ethical issues that arise in the context of religion and spirituality cannot be fully resolved by demarcating lines between psychology, religion, and spirituality. Instead, these issues call for a nuanced approach that embodies a respect for the richness and complexity of clients, psychotherapists, and the therapeutic process.

In short, future efforts to develop ethical standards should acknowledge the inherent "messiness" of this domain. Concrete steps are also needed to help practitioners address the complexity in this area. A few brief recommendations include the following: (a) develop ethical casebooks that probe deeply into the dilemmas that arise in spiritually integrated psychotherapy (see Richards \& Bergin, 2004); (b) create methods of assessment that are sensitive to the diverse array of clients' religious and spiritual needs, resources, and burdens; (c) mandate training on religious and spiritual issues in psychotherapy for all practitioners, because these issues cannot be fully compartmentalized or removed from even secular forms of treatment; (d) establish an empirical base of knowledge to guide psychotherapists in the appropriate and effective integration of religion and spirituality into treatment; (e) obtain informed consent from clients that acknowledges that, even though psychotherapy focuses on psychological issues, treatment may nevertheless impact them socially, physically, and spiritually; and (f) work together with pastoral counselors, hospital chaplains, and spiritual directors to grapple with these value and ethical issues and delineate points of commonality and departure among practices designed to enhance the human condition. 


\section{References}

Barbour, J. G. (1974). Myths, models and paradigms: A comparative study in science and religion. New York: Harper and Row.

Butter, E. M., \& Pargament, K. I. (2003). Development of a model for clinical assessment of religious coping: Initial validation of the process evaluation model. Mental Health, Religion and Culture, 6, 175-194.

Gonsiorek, J. C., Richards, P. S., Pargament, K. I., \& McMinn, M. R. (2009). Ethical challenges and opportunities at the edge: Incorporating sprituality and religion into psychology. Professional Psychology: Research and Practice, 40, 385-395.

Koenig, H. G., McCullough, M. E., \& Larson, D. B. (2001). Handbook of religion and health. Oxford, UK: Oxford University Press.

Pargament, K. I. (2007). Spiritually integrated psychotherapy: Understanding and addressing the sacred. New York: Guilford Press.

Richards, P. S., \& Bergin, A. E. (Eds.). (2004). Casebook for a spiritual strategy in counseling and psychotherapy. Washington, DC: American Psychological Association.

Rye, M., Pargament, K. I., Wei, P., Yingling, D. W., Shogren, K. A., \& Ito, M. (2005). Can group interventions facilitate forgiveness of an exspouse? A randomized clinical trial. Journal of Consulting and Clinical Psychology, 73, 880-892.

Tisdale, T. C., Keys, T. L., Edwards, K. J., Brokaw, B. F., Kemperman, S. R., Cloud, H., et al. (1997). Impact of treatment on God image and personal adjustment, and correlations of God image to personal adjustment and object relations adjustment. Journal of Psychology and Theology, 25, 227-239.

\section{Ethical Considerations With Spiritually Oriented Interventions}

\section{By Mark R. McMinn}

In his thoughtful article, Gonsiorek (Gonsiorek, Richards, Pargament, \& McMinn, 2009) addressed a number of important concerns regarding ethical practice with religious and spiritual issues in psychotherapy. Others responding to Gonsiorek have also made helpful elaborations and clarifications. Dr. Richards addressed the crucial issue of collaborating with clergy and other religious professionals - a topic that has been central to my professional and research work over the past decade (e.g., McMinn, Aikins \& Lish, 2003; McMinn, Meek, Canning, \& Pozzi, 2001). Dr. Pargament affirmed the complexity of ethical issues by noting that scientific inquiry and religion are not entirely distinct, which is a point that I would have certainly wanted to make in my commentary if he had not already done so (see also Jones, 1994). Instead, I focus my comments on Gonsiorek's final point, which he labels "What to Name It and Whether to Bill."

\section{Exploring the Area Between Nonproblematic and Fraudulent Practice}

Gonsiorek distinguished between services that are primarily psychological in nature and those that are religious, noting that some psychologists may gradually slide from one to the other while still billing insurance companies or clients for psychotherapy. This is a worthy point, and it is useful that he has identified the poles of nonproblematic and fraudulent practice, but there are many gradations between the anchors that Gonsiorek provided, making the demarcation between psychological interventions and religious services quite challenging. Consider the complexity of the following three examples.

If a Buddhist client is being treated with a mindfulness-based intervention, it might be quite natural for a religiously sensitive psychotherapist to discuss the connections between Buddhism and mindfulness in a session. This, I assume, would be an example of what Gonsiorek considers nonproblematic insofar as it is similar to his example of using the Biblical book of Job to help a Jewish or Christian client make sense of trauma. But at what point does religious sensitivity become religious education? Would it be appropriate in a psychotherapy session to reflect on one of the Buddha's sutras to help the client grasp the religious foundations of mindfulness? What about using 15-30 min of a psychotherapy session to try an explicitly spiritual meditation exercise as part of mindfulness training? Some psychologists would find an overt spiritual exercise such as this to be ethically problematic, whereas others would see it as culturally sensitive and appropriate.

Second, Gonsiorek mentioned spending a session in prayer as an inappropriate intervention for a psychologist. But what can be said of a psychologist who-at the client's request or with the client's permission- uses prayer in a portion of a psychotherapy session? In a video demonstrating Christian counseling, published as part of the American Psychological Association (APA) Psychotherapy Video series, I used an ancient prayer known as the Jesus prayer with a stressed client, and the results were visibly moving to the client and therapeutically helpful insofar as it helped her access the feelings associated with her stress (McMinn, 2006). Was this 5- to 10-min intervention too religious for a psychological intervention? There are clinical dangers to integrating prayer into psychotherapy, of course, including an escalation of the intrinsic power differential between psychologist and client, fostering increased levels of intimacy in the psychotherapy relationship, introducing subtle attempts to communicate indirectly with a client, and so on (McMinn, 1996), but the intentional use of prayer may still have a legitimate place in psychotherapy (Magaletta \& Brawer, 1998; Sperry, 2005; Tan, 1996).

Third, forgiveness research and interventions have proliferated in recent decades. What was once mostly a religious practice has been brought into mainstream psychotherapy. When a religious client chooses to forgive, might it be useful to help the client use spiritual strategies to engage in an arduous process that many clients still associate with their religious faith? It is fascinating that many hundreds of studies have been published on forgiveness, and dozens more on prayer, and yet very few studies focus on how prayer may be useful in the process of forgiveness. Preliminary research suggests that prayer is closely related to the forgiveness process for Christians (McMinn et al., 2008). What ethical concerns might arise if a psychologist assigns prayer as a homework strategy for a religiously committed client wanting to forgive a transgressor, or if the psychotherapist uses a prayer-based intervention in session for the same goal?

My point in mentioning these three examples is not to disagree with Gonsiorek, though I suspect we do disagree at least to some extent on matters of explicit integration (McMinn, 1996; Tan, 1996). He has done the profession a service by marking anchor points and calling one nonproblematic and the 
other fraudulent, but still we are faced with the more complex task of practicing ethically when a spiritually oriented intervention exceeds what is consensually identified as nonproblematic.

\section{Questions for Self-Reflection}

Dr. Richards offered several helpful questions for self-reflection in determining minimal competence. Similarly, I offer the following three questions with the hope that they may help clinicians continue useful conversations about ethical practice standards in those areas that involve some degree of religious intervention or education and thus exceed what Gonsiorek described as nonproblematic. This is not intended to be a comprehensive list but rather a list to prompt reflection and dialogue.

Question 1: Is this religiously or spiritually oriented intervention used in the context of an overarching psychological treatment plan?

Some treatment strategies may involve a degree of religious or spiritual education, such as the example of connecting mindfulness meditation with one of the Buddha's sutras mentioned above, but it seems important to distinguish between religious or spiritual education that is in service to an overarching psychological treatment plan from that which has spiritual or religious transformation as the primary goal. Psychologists provide psychological treatment, whereas spiritual directors, pastoral counselors, clergy, and other religious advisors offer services that address spiritual and religious transformation. Psychologists are generally not trained in methods of spiritual transformation, and even if they are trained, they typically bill for psychological services and are regulated by boards that monitor psychological qualifications, making it important to keep psychological methods and treatment goals at the forefront of the services that psychologists offer.

Question 2: Are the activities used in psychotherapy clearly documented, and would the psychologist reasonably expect concerns if the religious and spiritual interventions were known by a third-party payer?

Gonsiorek correctly noted that billing a patient or a payer for psychotherapy is fraudulent if the services provided are not psychotherapeutic. If a Christian psychologist offers a healing prayer intervention, with spiritual outcome goals and methods, then it would be unethical to bill for those services in a way that implies a standard psychotherapeutic intervention has been provided. But this becomes more complex when a spiritual intervention has been used within the context of a psychotherapeutic treatment plan. One helpful marker is for the psychologist to consider whether he or she is fully disclosing the treatment procedures in documenting the treatment. And, if so, how would the psychologist feel about providing the treatment records to a third-party payer?

For example, imagine the difference between a psychologist who studies the Torah with a Jewish client in order to promote godliness (a religiously oriented goal) and a psychologist who helps the client draw wisdom from the Torah to confront irrational beliefs that are contributing to anxiety (a psychologically oriented goal). In the latter case, the psychologist could presumably be clear and specific in the treatment record about the overall goals of the intervention, the particular spiritual strategies used, and so on. If an insurance company asked to see the psychologist's notes, they would find a clear and compelling psychological rationale for the spiritual interventions used in psychotherapy.

Question 3: Does the activity put the psychologist in a position of being accountable to competing regulatory bodies?

Psychologists are licensed by the state or province in which they practice. Historically, religious practitioners have been under the authority of a religious institution. If a psychologist begins offering spiritual direction or other services that have traditionally been under the authority of a religious community, two potential problems result. First, the psychologist risks practicing outside of the scope intended by the regulatory body issuing licenses to psychologists. Second, the psychologist also undermines the authority of the religious organization that sanctions spiritual direction practices.

The simplest solution is for psychologists to offer psychological services, and for spiritual directors, clergy, and pastoral counselors to offer spiritual services. But, as Pargament (2007) and others have noted, the distinctions between the psychological and the spiritual are not always clear cut. To some extent, all spiritually integrative psychotherapy holds the potential for spiritual transformation, and some psychologists have moved toward explicit spiritual transformation goals in their professional work (e.g., Benner, 2005; Sperry, 2005). For those psychologists who see spiritual transformation as part of their work, the issue of professional accountability needs to be carefully considered and communicated to the appropriate regulatory entities.

\section{Conclusion}

Gonsiorek has drawn our attention to an important conversation regarding the ethical implications of spiritually oriented practices. The ethical and practical issues are more complex than what can be explored in the brief articles here, calling psychologists to prolonged and nuanced conversations about how to understand and regulate spiritual and religious matters in psychotherapy.

\section{References}

Benner, D. G. (2005). Intensive soul care: Integrating psychotherapy and spiritual direction. In L. Sperry \& E. P. Shafranske (Eds.), Spiritually oriented psychotherapy (pp. 287-306). Washington, DC: American Psychological Association.

Gonsiorek, J. C., Richards, P. S., Pargament, K. I., \& McMinn, M. R. (2009). Ethical challenges and opportunities at the edge: Incorporating spirituality and religion into psychotherapy. Professional Psychology: Research and Practice, 40, 385-395.

Jones, S. L. (1994). A constructive relationship for religion with the science and profession of psychology: Perhaps the boldest model yet. American Psychologist, 49, 184-199.

Magaletta, P. R., \& Brawer, P. A. (1998). Prayer in psychotherapy: A model for its use, ethical considerations, and guidelines for practice. Journal of Psychology and Theology, 26, 322-330.

McMinn, M. R. (1996). Psychology, theology, and spirituality in Christian counseling. Wheaton, IL: Tyndale House. 
McMinn, M. R., Aikins, D. C., \& Lish, R. A. (2003). Basic and advanced competence in collaborating with clergy. Professional Psychology: Research and Practice, 34, 197-202.

McMinn, M. R., Fervida, H., Louwerse, K. A., Pop, J. L., Thompson, R. D., Trihub, B. L., et al. (2008). Forgiveness and prayer. Journal of Psychology and Christianity, 27, 101-109.

McMinn, M. R., Meek, K. R., Canning, S. S., \& Pozzi, C. F. (2001). Training psychologists to work with religious organizations: The Center for Church-Psychology Collaboration. Professional Psychology: Research and Practice, 32, 324-328.

Pargament, K. I. (2007). Spiritually integrated psychotherapy: Understanding and addressing the sacred. New York: Guilford.
Sperry, L. (2005). Integrative spiritually oriented psychotherapy. In L. Sperry \& E. P. Shafranske (Eds.), Spiritually oriented psychotherapy (pp. 307-329). Washington, DC: American Psychological Association.

Tan, S.-Y. (1996). Religion in clinical practice: Implicit and explicit integration. In E. P. Shafranske (Ed.), Religion and the clinical practice of psychology (pp. 365-387). Washington, DC: American Psychological Association.

Received September 10, 2008

Revised May 6, 2009

Accepted May 7, 2009 